\title{
Bernd Käpplinger
}

Humboldt-Universität zu Berlin

\section{Adult Education Research in Poland and Germany on the European Level: Two Sleeping Beauties?}

\author{
Badania nad edukacją dorosłych w Polsce i Niemczech \\ na szczeblu europejskim: dwie Śpiące Królewny?
}

\begin{abstract}
This paper analyzes Polish and German papers contributed to conferences of the European research society ESREA. The method "program analysis" is used. The analysis demonstrates that Polish and German researchers are present in this European forum for research in adult education. But there are also some shortcomings. Perspectives for further improvement are suggested and discussed.
\end{abstract}

Keywords: Adult education research, Poland, Germany, ESREA, program analysis.

Streszczenie. Niniejszy artykuł jest poświęcony analizie Polskich oraz Niemieckich referatów nadesłanych na konferencje Europejskiego Stowarzyszenia Badaczy Edukacji Dorosłych (ESREA). Użyto tutaj metody „program analysis”, dzięki której wykazano, że Polscy i Niemieccy naukowcy aktywnie uczestniczą w Europejskim forum dotyczącym badań nad edukacją dorosłych. Jednakże można zaobserwować tutaj pewne wady i braki. Niniejszy artykuł proponuje i omawia sugerowane zmiany.

Słowa kluczowe: badania nad edukacją dorosłych, Polska, Niemcy, ESREA, program analysis.

\section{Introduction}

Adult education research as academic subdiscipline is in Poland and Germany relatively well established. This might sound strange when perceiving it solely out of a national Polish or German insider perspective, where adult education research has also to struggle to receive adequate recognition in 
comparison to the education of young people. Nonetheless, when comparing the number of professors, chairs, academic staff or departments in the field of adult education in Poland and Germany with many other European countries the situations are relatively affluent. This is valid when considering countries like the Netherlands or the UK, where distinct chairs for andragology, andragogy or adult education have almost disappeared in the last decades. (c. Hake, 1992; Jones, 2014) Even in a country like Sweden (which is worldwide famous for its adult education as a popular practice) exists actually only one distinct chair for adult education ("Vuxenpedagogik") in Linköping. Adult education research is in some countries rather a part or a subject of social work or other sub disciplines. Considering these situations, it is interesting to analyze which role Polish and German researchers play on the European level of academic research on the education of adults. This will be done here on the basis of a "program analysis" of conference papers contributed by Polish and German researchers to the triennial research conferences of ESREA between 1995 and 2013.

\section{Approach and relevance}

A rich body of literature exists which deals with the international development of adult education research (Chang, 2013; Fejes \& Nicoll, 2013; Fejes \& Nylander, 2013; Larsson, 2010; Long, 1983; Rubenson, 1982, 2000; Rubenson \& Elfert, 2014; St. Clair, 2011; Taylor 2001). Mostly journals and much less frequently conferences have been analyzed. The analysis of Taylor (2001) of all submitted papers to a journal and not only accepted papers sheds some interesting light on selection processes of referred journals. Historically, there have been debates about the status and the goals of adult education as an independent field or discipline of research and its position within universities (e.g. Hake, 1992; Fejes \& Nicoll, 2013). Each scientific discipline has to assure itself what belongs to it and what not, although educational research might be sometimes habitually even more occupied with reflecting on and assuring its identity. Adult education as relatively young and volatile discipline might be still engaged to "cure the ills of an undisciplined discipline" (Plecas \& Sork, 1986) and to identify "centrifugal and centripetal forces" within the field (Gieseke et al., 1989). Analysis of internal processes of knowledge production within adult education is therefore useful in order to determine the development of disciplinary research. The paper aims to contribute here by shedding light on the European contribu- 
tions of Polish and German researchers. It is widely agreed that the international and also the European dimensions of adult education have increased in their importance in the last decades.

\section{The data and method}

The data analyzed: Papers of ESREA triennial research conferences

The data for this analysis are available papers of ESREA triennial research conferences. ESREA is the European Society for Research on the Education of Adults. It "promotes and disseminates theoretical and empirical research on the education of adults and adult learning in Europe through research networks, conferences and publications" as stated on the homepage of ESREA (www.esrea.org). ESREA compromises thus a wide range of activities (e.g. publishing the journal RELA). It organizes several conferences each year through its networks, but every third year they organize a bigger general research conference. ESREA triennial research conferences took place in different countries every three years since 1995 . These were the titles and gatherings of these triennials so far:

Strobl (1995): "Adult learning and social participation,"

Bruxelles (1998): "Learning to live in the learning society,"

Lisbon (2001): "Wider benefits of learning: understanding and monitoring the consequences of adult learning,"

Wrocław (2004): "Between 'old' and 'new' worlds of adult learning,"

Seville (2007): "Adult Learning and the challenges of social and cultural diversity: diverse lives, cultures, learnings and literacies,"

Linköping (2010): "Adult learning in Europe - understanding diverse meanings and contexts,"

Berlin (2013): "Changing configurations of adult education in transitional times."

To analyze conference papers and not articles in journals is a different approach from almost all other bibliometric analysis cited already. One advantage is that ESREA conferences have traditionally a low rejection rate (c. Antunes 2003). It gives a broader insight into the field of adult education research since journals are steered and more regulated by editors and reviewers (c. Taylor 2001).

The collection of the papers constituted a challenge since ESREA itself does not have an archive with conference papers. The papers could only 
be collected via the hosts of the conferences and via other people. ${ }^{1}$ The papers of ESREA1995 were edited in a book (Bisovsky et al., 1998). Similar is valid for ESREA2001 and ESREA2004 (ESREA2001; Bron et al., 2004). The papers of ESREA2004, ESREA2007, ESREA2010 and ESREA2013 were acquired as electronic data directly from the conference hosts. Unfortunately, data for ESREA1998 in Bruxelles could not be found despite extended efforts. The resulting sample consists out of 364 papers from six conferences:

\section{Table 1: ESREA conferences and number of avallable papers per conference}

\begin{tabular}{|c|c|c|c|c|c|c|}
\hline & $\begin{array}{c}\text { ESREA } \\
1995 \text { in } \\
\text { Strobl } \\
\text { (Austria) }\end{array}$ & $\begin{array}{c}\text { ESREA } \\
2001 \\
\text { in Lisbon } \\
\text { (Portugal) }\end{array}$ & $\begin{array}{c}\text { ESREA } \\
2004 \text { in } \\
\text { Wroctaw } \\
\text { (Poland) }\end{array}$ & $\begin{array}{c}\text { ESREA } \\
2007 \\
\text { in Seville } \\
\text { (Spain) }\end{array}$ & $\begin{array}{c}\text { ESREA } \\
2010 \text { in } \\
\text { Linköping } \\
\text { (Sweden) }\end{array}$ & $\begin{array}{c}\text { ES- } \\
\text { REA2013 } \\
\text { in Berlin } \\
\text { (Germany) }\end{array}$ \\
\hline $\begin{array}{c}\text { Num- } \\
\text { ber of } \\
\text { available } \\
\text { papers }\end{array}$ & 25 & 27 & 74 & 48 & 64 & 126 \\
\hline
\end{tabular}

Source: Author analysis

All data was saved or converted into Excel, Word and SPSS files for the respective analysis. Limitations of the data refer especially to the first two ESREA conferences where papers were only available via the publication. It is likely that the conferences itself assembled more papers than available via the publications. Nonetheless, ESREA triennial conferences have clearly increased in their participation over time.

\section{The method applied: Program analysis}

The data was analyzed by the method of mainly quantitative "program analysis," although the coding process resembles characteristics of qualitative

1 I am deeply thankful for the advice and support by Gerhard Bisovsky, Andreas Feyes, Barry Hake, Ewa Kurantowicz, Emilio Lucio-Villegas and Henning Salling-Olesen. 
interpretation of documents. ${ }^{2}$ The method refers overall to the content analysis of social sciences. It is often used especially in Germany in order to analyze the course offers of providers (see Gieseke, 2014; Schrader, 2014). Methodological discussions of the advantages and disadvantages of this method are available (e.g. Gieseke, 2000; Käpplinger, 2008). This method was applied to the analysis of conference papers of ESREA triennials. A similar approach was applied by Long (1983) for the Adult Education Research Conference (AERC) in Northern America in using a content analysis. A "program analysis" is a non-reactive method, which means that the data material is analyzed in retro-perspective by a coding researcher or a coding team of researchers. Each paper was coded accordingly a plan, which was deductively and inductively developed. The code plan consisted out of these variables:

- NAME: Names of the authors. Papers with multiple authorships were multi-coded per name.

- COUNTRY: The code was given accordingly the working places (institutional affiliation) of authors and not accordingly the country of birth.

- TITLE: Full title of paper.

- METHOD: Coded accordingly a revised coding plan developed and used by Long (1983)

- RESEARCH_FIELD: Coded according a plan originally developed by Arnold et al. (2000) and revised by Ludwig \& Baldauf-Bergmann (2010)

- NUMBER_CITATIONS: Quantitative amount of citations in the reference lists.

- GENDER_AUTHOR: Gender of the authors.

More details how the coding was done will be given in the following chapters.

\section{Results of the analysis}

The role of conference sites: Polish and German scholars are internationally visible

2 I am deeply thankful also for the work and support foremost by my assistant Mirko Ückert and my research team: Erik Haberzeth, Claudia Kulmus and Nina Lichte. They contributed differently to the coding of papers. This helped in achieving inter-coding-reliability, although this is an ideal to strive for in interpreting meaningful and context-sensible texts. 
The following map informs about the average participation rates in Triennials by countries. It is measured by the average participation rates of authors from different countries in relation to the numbers of all authors contributing per conference. ${ }^{3}$

\section{Figure 1: ESREA conferences and national participation rates}

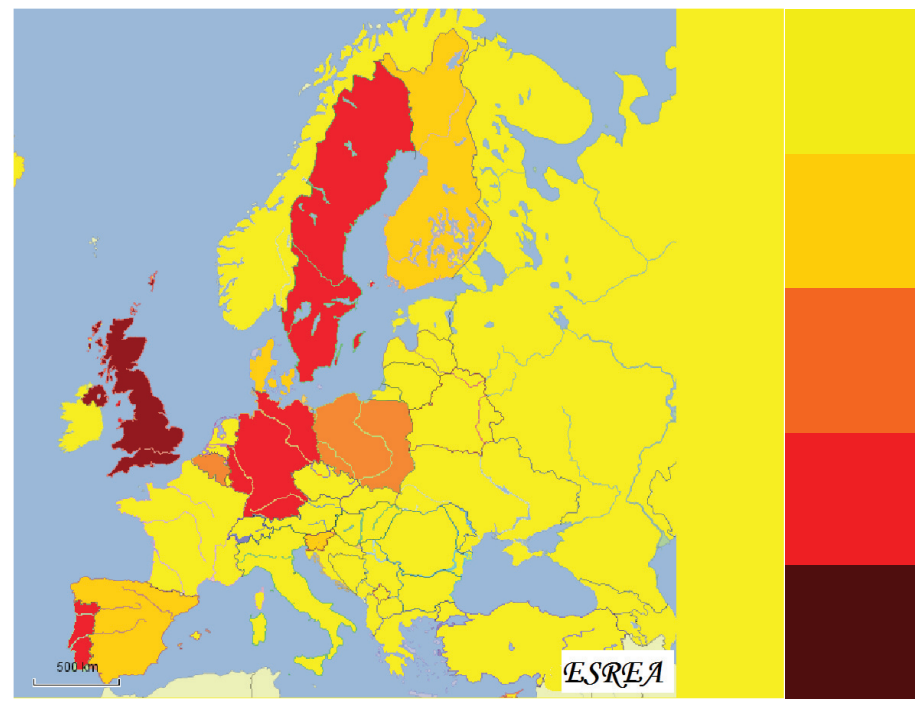

Average participa-

tion rate less than

$3 \%$

Average participa-

tion rate between

3 and $5 \%$

Average participa-

tion rate between

6 and $9 \%$

Average participa-

tion rate between

10 and $14 \%$

Average participation rate of $17 \%$

Source: Author analysis

When looking at the displayed map, it becomes clear that ESREA as a society is quantitatively influenced by the engagement of authors from a rather limited number of countries. The quantitatively most influential countries are the UK, Sweden, Portugal, Germany, Poland, Belgium, Denmark, Finland, Spain and Slovenia. Other countries contributed rather rarely to ESREA at least in quantitative terms. Country size matters of course, but it is not predetermining, when looking especially at France or Italy with relatively low representation in ESREA so far.

3 Since the different conferences have had a very different size in terms of participants the participation rate was calculated per each conference and the average of these averages was calculated. The average participation is the mean of all averages. 
Authors from the UK are overall the most active, which is certainly also caused by the lingua franca English within ESREA. Nonetheless, the relative importance of authors from the UK has clearly decreased over time. While British authors had a share of $30 \%$ (1995) or 37\% (2001) in relation to all contributions in ESREA triennial conferences, the last three conferences saw only a British participation rate of 6 to $9 \%$. A similar observation of a decreasing engagement over time can be made for Belgian or Slovenian authors. Contrarily, the shares of Portuguese and Swedish authors have increased over time. Spanish authors have been very engaged in their own national Triennial, which mainly led to their visual representation in the map. It is likely that other countries will increase their share, if the next ESREA triennial might be for example given to Estonia, France, Greece, Hungary or Italy. The table 2 below demonstrates clearly by the high national shares of scholars from the hosting country that many national authors take the chance to participate in an ESREA triennial when it is taking place in the own country. ${ }^{4}$ Polish or German scholars had very high shares of participants when the ESREA conference took place in Wrocław or Berlin. But countries' representation in the general map might be also diminishing over time when the impact of being a host becomes less influential by future conferences in other countries.

Table 2: ESREA conferences and the shares of authors from host countries

\begin{tabular}{|c|c|c|c|c|c|c|}
\hline & $\begin{array}{c}1995 \\
\text { Strobl }\end{array}$ & $\begin{array}{c}2001 \\
\text { Lisbon }\end{array}$ & $\begin{array}{c}2004 \\
\text { Wroctaw }\end{array}$ & $\begin{array}{c}2007 \\
\text { Sevilla }\end{array}$ & $\begin{array}{c}2010 \\
\text { Linköping }\end{array}$ & $\begin{array}{c}2013 \\
\text { Berlin }\end{array}$ \\
\hline $\begin{array}{c}\text { Share of authors } \\
\text { from the host } \\
\text { country in relation } \\
\text { to all authors in } \\
\text { the conference }\end{array}$ & $12 \%$ & $15 \%$ & $23 \%$ & $14 \%$ & $19 \%$ & $30 \%$ \\
\hline
\end{tabular}

Source: Author analysis

Finnish and Danish authors have been also visible in the different Triennials. Many other countries have had quantitatively rather marginal roles or

4 The pragmatic reason to avoid substantial traveling costs and having an international presentation or publication in nowadays internationalized publication regimes might be one important reason. 
a limited visibility. This might be related to the country size, "disciplines of scale" or the national academic engagement in adult education, but this is certainly not the explanation for France, Italy, the Netherlands or Norway. Also very challenging are the many underrepresented spots in vast parts of Central and Eastern Europe. The European map of research in adult education has a North-South and a West-East bias, although this bias is certainly eased because of the high engagement in countries like especially Poland, Slovenia, Portugal or Spain.

These results stimulate the impression that Polish and German adult education research is rather prominent in ESREA triennial conferences. This is partly true, but it is closely connected to hosting a conference. When looking at figure 2 this pattern becomes obvious.

Figure 2: Polish and German papers in ESREA triennial conferences (in absolute numbers)

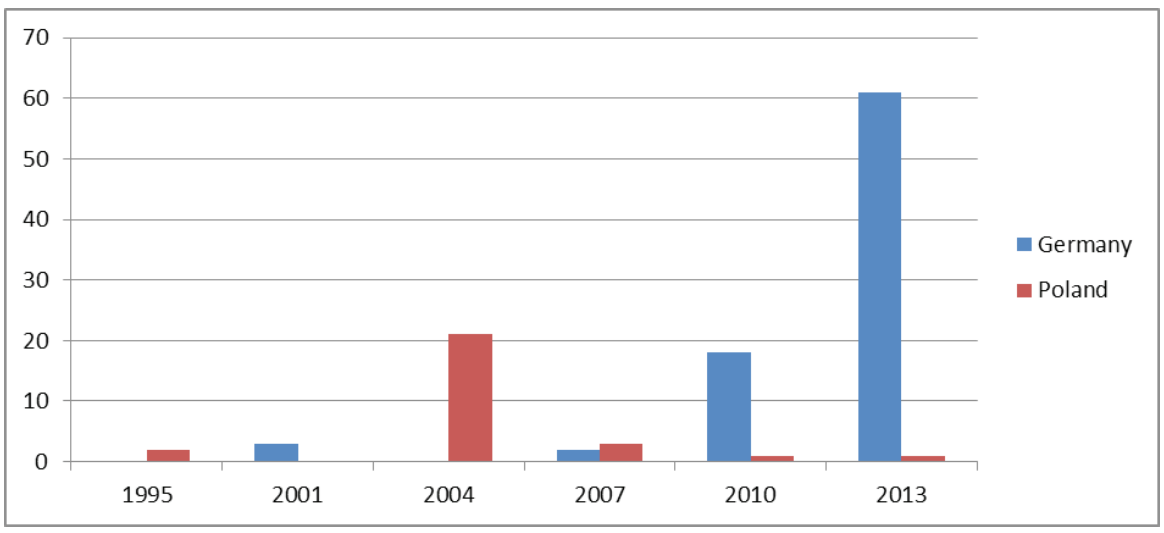

Source: Author analysis

Wrocław was the host in 2004 and Berlin in 2013. Beside these two conferences the shares of Polish and German scholars are rather peripheral. The only major exception is ESREA2010 in Sweden, which saw a bigger participation from German scholars. It will be interesting to follow how these patterns develop in future. Since it is not very likely that Poland or Germany will soon again host an ESREA triennial, it is not unlikely that both countries will become again "sleeping beauties." This is not untypical to many other countries on the European level. It highlights the national importance 
to host a European or international conference from time to time. Even in our virtual times gatherings in the real world are important learning places. It indicates also the need to find ways to engage more continuously on the European level by other means. Smaller workshops, joint research projects, the using of ICT and staff exchanges are only some measures in this respect.

\section{The methods and the Fields of Research}

Which methods and fields of research are most frequently used by adult education researchers over time? Based on the revised and updated typology ${ }^{5}$ of Long (1983) and the full papers of ESREA presenters the following results could be identified:

\section{Table 3: Papers in ESREA triennial research conferences by method (all countries)}

\begin{tabular}{|l|c|c|c|c|c|c|}
\hline & 1995 & 2001 & 2004 & 2007 & 2010 & 2013 \\
\hline Theoretical-philosophical & $40 \%$ & $30 \%$ & $23 \%$ & $2 \%$ & $3 \%$ & $12 \%$ \\
\hline Literature Review & $16 \%$ & $22 \%$ & $10 \%$ & $8 \%$ & $5 \%$ & $17 \%$ \\
\hline Historical & $0 \%$ & $0 \%$ & $1 \%$ & $10 \%$ & $6 \%$ & $3 \%$ \\
\hline Methodological & $8 \%$ & $0 \%$ & $4 \%$ & $8 \%$ & $5 \%$ & $2 \%$ \\
\hline Technique or Practice & $0 \%$ & $4 \%$ & $10 \%$ & $21 \%$ & $8 \%$ & $6 \%$ \\
\hline Qualitative-empirical & $12 \%$ & $26 \%$ & $36 \%$ & $29 \%$ & $39 \%$ & $31 \%$ \\
\hline Quantitative-empirical & $20 \%$ & $7 \%$ & $10 \%$ & $13 \%$ & $16 \%$ & $16 \%$ \\
\hline Triangulative & $0 \%$ & $4 \%$ & $7 \%$ & $8 \%$ & $17 \%$ & $12 \%$ \\
\hline Experimental and quasi-experimental & $4 \%$ & $0 \%$ & $0 \%$ & $0 \%$ & $2 \%$ & $1 \%$ \\
\hline Others & $0 \%$ & $7 \%$ & $0 \%$ & $0 \%$ & $0 \%$ & $2 \%$ \\
\hline
\end{tabular}

Source: Author analysis

5 "Theoretical-philosophical" papers are mainly based on arguments and general reasoning without explicit empirical analysis or even an own data collecting. "Literature reviews" are summarizing or analyzing mainly the existing body of literature. "Historical" papers make a historical analysis. "Technique or practice" are rather papers informed by the practice of adult education. Empirical papers have a qualitative focus, which mainly means in Adult education research to make interviews, while quantitative empirical research uses questionnaires. "Triangulative research" uses multi-method designs. Experimental and quasi-experimental as predominantly used in psychology or medicine is almost non-existing in adult education (c. Long, 1983, p. 95). 
Methods and approaches used have been changed over time. While it was popular to present mainly theoretical-philosophical papers in the early times of ESREA (e.g. in 1995 they have had a share of $40 \%$ in relation to all papers), nowadays empirical papers have a high share. It can be termed as an "empirical turn" of adult education research. Empirical papers are mainly focused on the qualitative paradigm (39\% in 2010). Quantitative papers and papers with triangulative approaches are also often presented (respectively $16 \%$ and $12 \%$ in 2013). Experimental and quasi-experimental papers are rather a peculiarity in adult education research. "Technique or practice" are papers, which are in a very strict or conservative sense not based on a clear separation between research and practice, but often rather refer to one origin of adult education as social movements. Such papers have had a peak in 2007, where the connections and interrelations between adult education and community education or social work were of pivotal interest for many papers. Relatively popular are also literature reviews (17\% in 2013), while historical research papers and methodological papers were rarely presented when looking at the general development. Overall, the most striking result is that the empirical focus of papers has increased. When summing up all empirical papers, their share on all papers has increased from $36 \%$ to $60 \%$ between 1995 and 2013. In 2010 their share was with 74\% even two times higher than in 1995. Within empirical research the qualitative paradigm is also twice more prominent than the quantitative paradigm. The Polish and German contributions differ a lot, when comparing the methods applied in the papers (see table 4).

Polish authors apply predominantly qualitative methods like interviews or the papers have often a theoretical-philosophical arguing. Other methods are relatively rare. The German authors apply nowadays almost equally qualitative and quantitative empirical methods or do even combine both in multi-method research designs. Theoretical-philosophical papers are relatively rare. Experimental or quasi-experimental papers are missing. When comparing both countries, the methods applied are similar in both countries for the qualitative approach and literature reviews. The usage of the other intensively used methods differs significantly between Poland and Germany. This might limit the chances to do joint research or to exchange research results, but it might be also the opportunity to make complementary usage of the differing approaches in both countries. Both countries are lacking experimental and quasi-experimental research. This might be a voluntary decision and specific to adult education research in contrast to other disciplines. Nonetheless, it should be reflected if this is merely a tradition- 
al reluctance. Is adult education research perhaps not creative or innovative enough here to research by using experimental approaches? Is there really no added value imaginable by using experiments? It might be too easy to explain this absence of a generally popular method in science by ethical reasoning, which is of course crucial when doing experiments.

Table 4: Papers in ESREA triennial research conferences by method (Poland and Germany for all years)

\begin{tabular}{|l|c|c|}
\hline & Poland & Germany \\
\hline Qualitative-empirical & $48 \%$ & $29 \%$ \\
\hline Quantitative-empirical & $8 \%$ & $33 \%$ \\
\hline Theoretical-philosophical & $24 \%$ & $6 \%$ \\
\hline Triangulative & $4 \%$ & $18 \%$ \\
\hline Literature Review & $8 \%$ & $10 \%$ \\
\hline Methodological & $4 \%$ & $4 \%$ \\
\hline Technique or Practice & $4 \%$ & $0 \%$ \\
\hline Experimental and quasi-experimental & $0 \%$ & $0 \%$ \\
\hline Total & $100 \%$ & $100 \%$ \\
\hline
\end{tabular}

Source: Author analysis

The learning of adults is connected to various perspectives and different content. There is a triangle between learner, teacher and content. This triangle can be framed by institutional and organizational environments, which are also part of a wider context of systems (labor market, political systems, cultures, etc.) and policies of state agencies and other interest groups or stakeholders. Arnold et al. (2000, see also Ludwig \& Baldauf-Bergmann, 2008) refer on such a pentamerous systematization when structuring the field of research in adult education. After coding ESREA papers based on these five types, the following overview can be made for Poland and Germany: 
Table 5: Papers in ESREA triennial research conferences by content (all countries)

\begin{tabular}{|l|c|c|c|c|c|c|}
\hline & 1995 & 2001 & 2004 & 2007 & 2010 & 2013 \\
\hline Systems and Policies & $52 \%$ & $48 \%$ & $19 \%$ & $21 \%$ & $25 \%$ & $32 \%$ \\
\hline Learning of Adults & $12 \%$ & $26 \%$ & $40 \%$ & $27 \%$ & $34 \%$ & $25 \%$ \\
\hline Professional Action & $8 \%$ & $0 \%$ & $14 \%$ & $19 \%$ & $8 \%$ & $19 \%$ \\
\hline Knowledge and Competences & $20 \%$ & $22 \%$ & $14 \%$ & $15 \%$ & $9 \%$ & $18 \%$ \\
\hline Institutions and Organizations & $8 \%$ & $4 \%$ & $14 \%$ & $19 \%$ & $23 \%$ & $7 \%$ \\
\hline Total & $100 \%$ & $100 \%$ & $100 \%$ & $100 \%$ & $100 \%$ & $100 \%$ \\
\hline
\end{tabular}

Source: Author analysis

A high mobility between conferences becomes again visible. It is no trend observable that any content field is clearly increasing or decreasing over time, but focus points become visible. The wider context of systems and policies has been very prominent in the past (see ESREA1995), but after a sharp drop happened after 2004. Contrarily, institutions and organizations in which teaching and learning takes place are not as prominent as research subjects as especially learners or partly teachers. The content of learning (knowledge and competences) had been never a core or top interest in the majority of papers. Overall, the learners, systems and policies have been very often the mostly used focus of papers. It might be an observation that adult education research often oscillates between the individual and the societal, while intermediating institutions and professions are sometimes less prominent or even neglected.

When combining the above mentioned methods and fields of research, the most frequent combination in a Triennial is a qualitative study on the learning of adults ( $13.5 \%$ of all papers). This is clearly the most popular form, which means very often doing interviews with learners (c. Antunes, 2003, p. 72). The next frequent forms (8.8\%) are theoretical-philosophical papers on systems and policies. The following configuration is a literature review (6.6\%) with the same focus. Then can be found qualitative studies on educational personal (6.1\%) or on institutions/organizations (5.2\%). The first quantitative combination follows on $6^{\text {th }}$ place with $5.0 \%$ and is focused on the learners. Studies on knowledge/competences and organizations/institutions had been only rarely been done. 
The results for Poland and Germany are looking as following (see table 6):

Table 6: Papers in ESREA triennial research conferences by method (Poland and Germany for all years)

\begin{tabular}{|l|c|c|}
\hline & Poland & Germany \\
\hline Learning of Adults & $44 \%$ & $28 \%$ \\
\hline Professional Action & $32 \%$ & $14 \%$ \\
\hline Systems and Policies & $12 \%$ & $31 \%$ \\
\hline Knowledge and Competences & $8 \%$ & $20 \%$ \\
\hline Institutions and Organizations & $4 \%$ & $8 \%$ \\
\hline Total & $100 \%$ & $100 \%$ \\
\hline
\end{tabular}

Source: Author analysis

The Polish research has a strong focus on educators or on learners with special attention to the wider context of policies and systems. German scholars are even more occupied with policies and systems, while professional actions of educators are not as prominent as one might or should actually expect from an educational discipline. It seems to be a challenge that the actual educational actions between learners and educators are less researched by German scholars. It is contrarily also striking that knowledge and competencies are relatively intensively researched in Germany, while scholars in Poland seem to have - at least in the past - not intensively researched about the outcomes of learning and the ways how knowledge is acquired in learning processes by learners. Overall, the research in Poland and Germany exhibit quite a number of significant different focus points so far. It might deserve continued and even intensified insights how these gaps can be bridged, but also how we might be able to learn mutually from each other, because of the different approaches and different interests. The mainly quantitative approach here gives so far only an overview. 


\section{Summary}

When returning to the initial question in the title of this paper, it can be stressed that Poland and Germany are not "sleeping beauties" on the European level. They are already quite vividly present in the European map of adult education research. They are even landmarks when comparing both countries with their neighbors, which are really rather absent (e.g. Czech Republic, France, Italy, the Netherlands) at least in relation to ESREA. Other countries like the UK are of rather decreasing importance in the last decade. While scholars like Kulich (1989) saw in the past Yugoslavia as a country with intensive andragogy research and in the 1990s Slovenia was considered as a place, where in Middle and Eastern Europe intensive research on the education of adults is taking place (c. Spolar, 2014), Polish scholar are most active in the last two decades. It will be interesting to see how the situation develops in the future. Adult education and andragogy are everywhere academic sub disciplines, which have to struggle for an adequate position in universities. The slogan of lifelong learning has not changed this or even increased problems (c. Martin, 2000; Popovic, 2013). Other disciplines like sociology, psychology or economics have increased (again) there interests in adult education. It has become much more prestigious to research on this issue, which is at stake for policy-makers and transnational organizations like the EU or the OECD. Adult education research should avoid to consider the own academic position as being granted.

Overall, the situation is far from being gloomy for Poland and Germany. This is especially not the case since Poland as well as Germany had been hosts of a ESREA triennial research conference. Nonetheless, further engagement is needed since it is unlikely to see such a conference happening soon again in Poland or Germany. The analysis presented here demonstrates some significant differences between adult education research in Poland and Germany. More and deeper insights are needed in order to understand better these differences. (c. Höhn et al., 1997) Complementary approaches are also an option. (c. Góralska/Solarczyk, 2013; Gieseke, 2011) Overall, there seems to be a lot of space for learning mutually from each other and to research in joint research projects (Gieseke/Kargul, 2005). 


\section{References}

Antunes, M. H. (2003). Comments to Selection Process and Conference Papers. In ESREA (ed.). Wider Benefits of Learning: Understanding and Monitoring the Consequences of Adult Learning. Triennial ESREA 2001 Conference (pp. 67-72). Lisbon: Lusófona University.

Arnold, R. et al. (2000). Forschungsmemorandum für die Erwachsenen- und Weiterbildung. Frankfurt/Main: Deutsches Institut für Erwachsenenbildung.

Bisovsky, G. et al. (1998). Adult Learning and Social Participation. Wien: Verband Wiener Volksbildung.

Bron, A. \& Kurantowicz, E. \& Salling Olesen, H. \& West, L. (2005). 'Old' and 'New' Word of Adult Learning. Wrocław: Wydawnictwo Naukowe Dolnośląskiej Szkoły Wyzsżej Edukacji.

Chang, B. (2013). Shift of Adult Education Research. Proceedings of the Adult Education Research Conference 2013 (pp. 63-69). Penn State University.

ESREA (2003). Wider Benefits of Learning: Understanding and Monitoring the Consequences of Adult Learning. Triennial ESREA 2001 Conference. Lisbon: Lusófona University.

Fejes, A. \& Nicoll, K. (2013). Approaches to research on the education and learning of adults. European Journal for Research on the Education and Learning of Adults, 4 (1), 7-14.

Fejes, A. \& Nylander, E. (2013). Defining the field of research on the education and learning of adults. A bibliometrical and content analysis of three adult education journals 2005-2012. Paper presented at the Seventh ESREA triennial European research conference. Berlin: Humboldt-University Berlin, 4-7 September 2013.

Garfield, S. (2013). On the Map - Why the World Looks the Way it Does. London: Profile Books.

Gieseke, W. (2014). Adult and Continuing Education: Results in the Context of Research. In B. Käpplinger \& S. Robak, Changing configuration in adult education in transitional times: international perspectives in different countries (pp. 153-174). Frankfurt/Main: Lang.

Gieseke W. (2011). Programy i badania programów jako specyficzna wiedza sterująca dla instytucji edukacji dorosłych? In „Rocznik Andragogiczny” 2011, Akademickie Towarzystwo Andragogiczne, Uniwersytet Warszawski, Warszawa-Torun, s. 34-46.

Gieseke, W. \& Kargul, J. (eds.) (2005). Europäisierung durch Kulturelle Bildung. Bildung-Praxis-Event.

Volume 1: Gieseke, W. \& Opelt, K. \& Stock, H. \& Börjesson, I.: Kulturelle Erwachsenenbildung in Deutschland - Exemplarische Analyse Berlin/Brandenburg. Berlin: Waxmann.

Volume 2: Depta, H. \& Kargul, J. \& Półturzycki, J. (eds.): Kulturelle Erwachsenenbildung in Polen am Beispiel Lubuskie, Warschau und Płock. Münster: Waxmann. 
Volume 3: Deutsch-polnische Forschergruppe (eds.): Interkulturelle Betrachtungen Kultureller Bildung in Grenzregionen - mit Buckower Empfehlungen. Humboldt-Universität zu Berlin, Erwachsenenpädagogischer Report 6, Berlin.

Gieseke, W. (ed.) (2000). Programmplanung als Bildungsmanagement? Recklinghausen: Bitter.

Gieseke, W. et al. (eds.) (1989). Zentrifugale und zentripetale Kräfte in der Disziplin Erwachsenenbildung. Heidelberg: Arbeitsgruppe für Empirische Bildungsforschung.

Gieseke W. (2011). Programy i badania programów jako specyficzna wiedza sterująca dla instytucji edukacji dorostych? In „Rocznik Andragogiczny” 2011, Akademickie Towarzystwo Andragogiczne, Uniwersytet Warszawski, Warszawa-Toruń, s. 34-46.

Góralska R. \& Solarczyk H. (2013). Emotionsforschung in Polen. In Käpplinger B. \& Robak S. \& Schmidt-Lauff S. (Hrsg.), Engagement für die Erwachsenenbildung, Ethische Bezugnahmen und demokratische Verantwortung, Wiesbaden: Springer, S. 43-53.

Hake, B. J. (1992). Remaking the study of adult education: The relevance of recent developments in the Netherlands to the search for disciplinary identity. Adult Education Quarterly, 42, 63-78.

Höhn W. \& Gieseke W. \& Kaczor S. (Hrsg.) (1997). Probleme der Erwachsenenbildung in Polen und Deutschland, Wydawnictwo i Zakład Poligrafii Instytutu Technologii Eksploatacji, Berlin-Radom-Warschau.

Jones, W. (2014). The present and future situation of adult educators in the United Kingdom. In B. Käpplinger \& S. Robak, Changing configuration in adult education in transitional times: international perspectives in different countries (pp. 139-152). Frankfurt/Main: Lang.

Käpplinger, B. (2008). Programmanalysen und ihre Bedeutung für pädagogische Forschung. Forum Qualitative Social Research, 9 (1), http://www.qualitativeresearch.net/index.php/fqs/article/view/333.

Kulich, J. (1989). Provision in Eastern Europe and the Soviet Union. In Titmus, C. J. (ed.). Lifelong Education for Adults - An International Handbook. (pp. 407-414) Exeter: Pergamon Press.

Larsson, S. (2010). Invisible colleges in the adult education research world. European Journal for Research on the Education and Learning of Adults, 1 (1-2), 97$-112$.

Long, H. B. (1983). Characteristics of Adult Education Research Reported At the Adult Education Research Conference, 1971-1980. Adult Education Quarterly, 33, 79-96.

Ludwig, J. \& Baldauff-Bergmann, J. (2010). Profilbildungsprobleme in der Erwachsenenbildungsforschung. REPORT, 1 (33), 65-76.

Martin, I. (2000). Reconstituting the Agora: Towards an Alternative Politics of Lifelong Learning. In T. Sork, V. Chapman \& R. St. Clair (eds.), Proceedings of the Adult Education Research Conference 2000. Vancouver: UBC. 
Olesen, H. S. (2014). Adult Education in the Danish Modernization Process. In B. Käpplinger \& St. Robak (eds.). Changing configuration in adult education in transitional times: international perspectives in different countries (pp. 39-56). Frankfurt/Main: Lang.

Plecas, D. B. \& Sork, T. J. (1986). Adult Education: Curing the Ills of an Undisciplined Discipline. Adult Education Quarterly, 37, 48-62.

Popovic, K. (2013). Adult Education - Lost in a Transition? Non-published key note at the $7^{\text {th }}$ ESREA Triennial. Berlin.

Rubenson, K. (1982). Adult education research: In quest of a map of the territory. Adult Education Quarterly, 32 (2), 57-74.

Rubenson, K. (2000). Revisiting the map of the territory. Conference Proceedings of the Canadian Association for the Study of Adult Education, 2000.

Rubenson, K. \& Elfert, M. (2014). Changing Configurations of Adult Education Research: Exploring a Fragmented Map. In B. Käpplinger \& St. Robak (eds.). Changing configuration in adult education in transitional times: international perspectives in different countries (pp. 25-38). Frankfurt/Main: Lang.

Schrader, J. (2014). Strategies of Modernisation and Their Effects on Configurations of Adult Education. In Adult and Continuing Education: Results in the Context of Research. In B. Käpplinger \& S. Robak (eds.). Changing configuration in adult education in transitional times: international perspectives in different countries (pp. 57-71). Frankfurt/Main: Lang.

Spolar, Vida A. M. (2014). Education and Training for Adult Education Profession in Slovenia before and after the Transition Period. In B. Käpplinger \& S. Robak (eds.). Changing configuration in adult education in transitional times: international perspectives in different countries (pp. 191-210). Frankfurt/Main: Lang.

St. Clair, R. (2011). Writing ourselves into being: A review of the Canadian Journal for the Study of Adult Education. Canadian Journal for the Study of Adult Education, 23 (2), 27-44.

Taylor, E. W. (2001). Adult Education Quarterly from 1989 to 1999: A content analysis of all submissions. Adult Education Quarterly, 51 (4), 322-340. 
